\title{
Could severe mobility and park use restrictions during the COVID-19 pandemic aggravate health inequalities? Insights and challenges from Latin America
}

\author{
¿Podrían las rigurosas restricciones de movilidad \\ y uso de parques durante la COVID-19, agravar \\ las inequidades de salud? Percepciones y \\ desafíos desde Latinoamérica
}
As restrições severas sobre mobilidade e uso de parques durante a pandemia da COVID-19 podem agravar as desigualdades em saúde? Relatos e desafios na América Latina

\author{
Andrea Cortinez-O’Ryan 1,2 \\ Mika Ruchama Moran 3 \\ Ana Paola Rios 4 \\ Cecilia Anza-Ramirez 5 \\ Anne Dorothée Slovic 6
}

doi: 10.1590/0102-311X00185820
Parks are important for local populations, especially during the pandemic and shelter-in-place orders. The coronavirus disease (COVID-19) reached Latin America at the end of February 2020, about a month later than Europe and around two months after Asia. Latin America is among the most urbanized and unequal world regions and, as such, the policies implemented to contain the pandemic, such as mobility restrictions and park closures, may affect health-enhancing behaviors of the wealthy and poor differently. Such unintended consequences deserve a closer examination when confinement and future deconfinement measures are considered and planned.

Parks and "green spaces" offer psychological restoration and ease mental health challenges (stress, anxiety, and depression), which are currently rising due to the pandemic and quarantine policies 1. Parks also provide opportunities for physical activity practices in social distancing, which can increase resilience to the COVID-19 by preventing and controlling chronic conditions such as obesity, hypertension, and cardiovascular diseases 2,3. However, parks can also provide hubs for community transmissions.

This duality, in which parks are protective spaces, but also a potential source of risk, is mirrored in the variety of different (and sometimes opposing) park-related lockdown policies adopted by governments worldwide. In several Northern countries, during stay-at-home orders, people were encouraged to visit parks for exercise while social distancing, and leading health agencies (World Health Organization and U.S. Centers for Disease Control and Prevention) recommended park use during the pandemic for several health benefits. However, restrictions in park use were often implemented. For example, in New York City, which was most strongly affected from COVID-19 in the United States, playgrounds use was suspended, and the number of park visitors was monitored in early May 2020 to prevent overcrowding 4 . While these are examples from one city, such strategies were used in other cities across the United States and Canada 5,6.

In Latin America, however, no recommendations for safe park use were provided and restrictions on parks were generally more severe. For example, parks were closed to the public as lockdown was imposed in Peru, Colombia, Chile, and some Brazilian districts, and mobility restrictions excluded opportunities for minimal activity, such as walking outdoors in Chile, Peru, and Colombia 7,8,9,10.
1 Facultad de Medicina, Pontificia Universidad Católica de Chile, Santiago, Chile.

2 Facultad de Educación, Ciencias Sociales y Humanidades, Universidad de la Frontera, Temuco, Chile.

3 Institute of Urban and Regional Development, University of California Berkeley, Berkeley, U.S.A.

4 Unidad de Terapia Cardiorrespiratoria, Universidad Manuela Beltrán, Bogotá, Colombia. 5 CRONICAS Centro de Excelencia en Enfermedades Crónicas, Universidade Peruana Cayetano Heredia, Lima, Perú.

6 Faculdade de Saúde Pública, Universidade de São Paulo, São Paulo, Brasil.

\section{Correspondence} A. Cortinez-O'Ryan Moneda 673 piso 8 , Santiago, Chile. andrea.cortinez@ufrontera.cl 
This occurred despite important health benefits, especially for children, older adults, and people with chronic diseases. The extension of these restrictions regarding territory and duration may threaten the health of large populations. For example, in Chile, the first lockdown (March 26th) included only seven districts of the capital; however, park access was prevented across all the country since March 17 th, when the national park network was closed. This measure was adopted regardless of the varying epidemiological situations of each region. Parks remained closed 80 days later, even where lockdown had been lifted 11,12. In Santiago, 106 days after the lockdown was enacted, there was still no permission to escort children or older adults to walk outside. However, allowances were made for taking pets out for 30 minutes 11 .

Low compliance with confinement measures, crowding in public spaces, and misuse of permits have been noticed in Latin American capitals 13,14 and they may contribute to the authorities' reluctance to ease restrictions. Over time, Latin American countries are slowly easing the restrictive measures. In some districts of Bogotá (Colombia) and Lima (Peru), children were allowed to walk outside, overseen by an adult, after two months since the lockdown was issued 15,16. Despite their potential health benefits, these changes reflect governments' political consideration rather than data-driven decisions, as no decrease in COVID-19 cases was observed at the time they were employed (Johns Hopkins University \& Medicine. COVID-19 Dashboard by the Center for Systems Science and Engineering (CSSE) at Johns Hopkins University (JHU). https://coronavirus.jhu.edu/map.html, accessed on $05 / \mathrm{Jun} / 2020$ ).

The severe and homogeneous restrictions can increase existing intra-urban health inequities in Latin America. Residents of affluent neighborhoods are likely to have enough space at home to maintain exercise routines, whereas in low-income neighborhoods the limited and substandard indoor space turns public spaces into the only opportunities to remain active. Banning public spaces use during a lockdown deprives the few opportunities for activity and restoration in such manner that punishes the poor to a greater extent, and makes them pay an additional "health fee" for complying with the lockdown. Therefore, imposing strict homogeneous lockdown policies may not only adversely affect the most vulnerable, but also increase pre-existing health inequalities related to precarious conditions of underserved territories.

These inequalities are especially concerning, considering the reported decreases in physical activity since the outbreak of COVID-19, especially among vulnerable populations as children and older adults 17 . In Mexico, children's daily screen time doubled while physical activity and sleep time decreased significantly during the pandemic (A. Jáuregui, 2020; personal communication). In Chile, children's physical activity decreased by one third, screen time doubled, and sleep quality worsened (N. Aguilar-Farías, 2020; personal communication). In Brazil, residents of lower quality neighborhood as well those unemployed presented reduced physical activity during this pandemic 18 .

Despite these concerning pieces of evidence, measures that hinder physical activity are naturalized, and debates on strategies to prevent such detrimental health effects are generally absent in the Latin American public discourse. Regulating park use and outdoor recreation is essential for all, especially for children, older adults, and people with chronic health conditions.

Despite its importance, regulated park use by itself would not be sufficient to provide egalitarian access to outdoors recreation during the pandemic since, to large underserved populations that reside in excluded peripheral areas of cities, quality parks would still be distant and, if present, unsafe. Substandard parks located in such neighborhoods are likely avoided even more than usual during the pandemic since the habitual violence that is present in marginalized areas of Latin America increased under confinement 19 . Several policies need to be considered to promote equitable and safe access to parks and outdoors recreation. Firstly, park hours can be extended and visits can be scheduled. Besides existing parks, other spaces can be opened to the public, such as soccer fields and school yards. Where parks are insufficient and unsafe, underused city space, such as streets or parking lots, can be enabled and further activated by programs and tactical urbanism. Such strategies have been long used in the region and they were proved to be cost-effective and successful, including: The ciclovía of Bogotá (open streets); Colombian recreovias and "Ecuador Ejercítate" (free outdoors physical activity classes with music); "Juega en tu Barrio" and "CicloRecreoVia" of Chile (streets play and open streets); and new on-road cycle paths $20,21,22$. Such strategies, along with socially inclusive programs, may increase residents sense of safety 23 and, ultimately, reduce health inequalities during the pandemic. 
Considering the geographically evolving behavior of the pandemic, these policies should be employed at the local governance, rather than a fixed centralized policy, and they should be adapted for each communities' needs.

From a broader socio-political perspective, even though the COVID-19 outbreak increased inequalities in Latin America, they existed long before the pandemic. In recent years, radical economic policies imposed by settled privileged groups have reverted the rights and welfare previously achieved. This, associated with chronic and marked inequality of this region, configure an inauspicious and unequal socio-sanitary scenario that becomes increasingly evident as the pandemic unfolds. The pandemic's differing consequences across economic groups may elevate the tension and lead to violent social outbreaks as the ones in Ecuador and Chile in 2019, where protesters massively claimed for dignity and rejected precarization of life. Social and sanitary crises could raise the need to revalue social welfare and call countries to reflect on novel political and economic possibilities. Green and health-enhancing urban policies (cycle paths, tactical urbanism), which have been employed in Latin American cities previously and during the pandemic, should be considered as long-term sustainable policies to reduce urban health inequalities during and post pandemic.

As cities start the deconfinement, the opening of commerce and services are governmental priorities. However, along with the debate of more social and ecologically sustainable economic models, policies in line with such models, such as the re-opening of parks and the provision of new spaces for recreation, especially in underserved neighborhoods, should not be postponed. A number of measures can be adopted to allow safe park use and outdoor recreation, and they must be organized with a strong sense of urgency. Enabling routine physical activities and psychological restoration is essential during the lockdown, as well as post-pandemic considering the significant expected increase in chronic diseases and mental health conditions 24,25 .

Measures' severity and extension need cautious weighting so they yield more benefits than the health risks they pose, particularly amongst vulnerable populations that already accumulate greater health risks. Thoughtful strategies need to be built to allow vulnerable population to perform safe outdoors physical activity during the confinement and re-opening stages. These need to be accompanied by a preparation of existing spaces such as parks, the provision of new additional spaces, and a strong communicational strategy to increase awareness and encourage responsible behaviors.

Confinement measures have been in place for prolonged periods in our region and might be reimposed in the future in Latin America and other regions if spikes recur. Understanding and quantifying their effects on health disparities is critical to better inform decision making and public policy development regarding restrictions that affect physical activity and psychological restoration. This will also enhance preparedness for eventual future pandemics. The lagging stage of the pandemic in Latin America provides an opportunity to adopt responsible re-opening models and learn from successful phased strategies implemented by other countries. These require cautious adaptations according to the local cultural aspects and the physical and social environmental features of our countries. Adopting timely measures to regulate safe park use and outdoor recreation in Latin American cities is critical and should be a public health priority. 


\section{Contributors}

A. Cortinez-O'Ryan, M. R. Moran and A. D. Slovic participated in the article conception, writing, and review. A. P. Rios and C. Anza-Ramirez contributed writing and reviewing the article.

\section{Additional informations}

ORCID: Andrea Cortinez-O'Ryan (0000-00016207-3377); Mika Ruchama Moran (0000-00024225-0388); Ana Paola Rios (0000-0001-96716406); Cecilia Anza-Ramirez (0000-0001-73648252); Anne Dorothée Slovic (0000-0002-47805813).

\section{Acknowledgments}

The Salud Urbana en América Latina (SALURBAL) project is funded by the Wellcome Trust. The authors acknowledge the contribution of all SALURBAL project team members, and is especially grateful to the members of the parks and health working group who provided ideas and inspiration for this article. For more information on SALURBAL and to see a full list of investigators access: https:// drexel.edu/lac/salurbal/team/. To Wellcome Trust $[205177 / \mathrm{Z} / 16 / \mathrm{Z}]$ for the financial support.

\section{References}

1. Holmes EA, O'Connor R, Perry VH, Tracey I, Wessely S, Arseneault L, et al. Multidisciplinary research priorities for the COVID-19 pandemic: a call for action for mental health science. Lancet Psychiatry 2020; 7:547-60.

2. Petrakis D, Margină D, Tsarouhas K, Tekos F, Stan M, Nikitovic D, et al. Obesity a risk factor for increased COVID-19 prevalence, severity and lethality. Mol Med Rep 2020; 22:9-19.

3. Kass DA, Duggal P, Cingolani O. Obesity could shift severe COVID-19 disease to younger ages. Lancet 2020; 395:1544-5.

4. NYC Parks. Important parks department service changes due to the coronavirus (COVID-19). https://www.nycgovparks.org/ about/health-and-safety-guide/coronavirus (accessed on 06/Jun/2020).

5. Chicago Park District. Chicago Park District response to coronavirus (COVID-19). https:// www.chicagoparkdistrict.com/coronavirusresponse (accessed on 06/Jun/2020).

6. City of Toronto. COVID-19: changes to city services - parks. https://www.toronto.ca/ home/covid-19/covid-19-latest-city-of-toron to-news/affected-city-services/ (accessed on 05/Jun/2020).

7. Ministerio del Interior. Decreto no 457, de 22 de marzo de 2020. Por el cual se imparten instrucciones en virtud de la emergencia sanitaria generada por la pandemia del coronavirus COVID-19 y el mantenimiento del orden pública. https://dapre.presidencia.gov.co/nor mativa/decretos-2020/decretos-marzo-2020 (accessed on 02/Jun/2020).

8. Ministerio de Desarrollo e Inclusión Social. Resolución Directoral no 050-2020-MIDIS https://www.gob.pe/institucion/pcm/nor mas-legales/466415-050-2020-midis-p65-de (accessed on 02/Jun/2020).

9. Ministerio de Salud. Resolución 203 Exenta. https://www.leychile.cl/Navegar?idNorma=11 43703\&idParte $=0$ (accessed on 04/Jun/2020).

10. Prefeitura de São Paulo. Decreto no 59.290, de 19 de março de 2020. Determina o fechamento dos parques municipais, sob a gestão da Secretaria Municipal do Verde e do Meio Ambiente, bem como do Parque das Bicicletas e do Centro Esportivo, Recreativo e Educativo do Trabalhador - CERET. Diário Oficial da Cidade de São Paulo 2020; 20 mar.

11. Ministerio de Salud. Resolución 210 Exenta. https://www.leychile.cl/Navegar?id Norma $=1143802$ (accessed on 04/Jun/2020).

12. Ministerio de Vivienda y Urbanismo. Minvu anuncia cierre de toda su red de parques urbanos a lo largo del país de manera indefinida. https://www.minvu.cl/noticia/noticias/minvuanuncia-cierre-de-toda-su-red-de-parques-ur banos-a-lo-largo-del-pais-de-manera-indefini $\mathrm{da} /$ (accessed on 04/Jun/2020). 
13. Castañeda DR. Durante la cuarentena se han impuesto cada día más de 6.600 comparendos Asuntos:Legales 2020; 30 may. https://www. asuntoslegales.com.co/actualidad/durante-lacuarentena-se-han-impuesto-cada-dia-masde-6600-comparendos-3012214.

14. Brasil. Lei no 13.979, de 6 de fevereiro de 2020. Dispõe sobre as medidas para enfrentamento da emergência de saúde pública de importância internacional decorrente do coronavírus responsável pelo surto de 2019. Diário Oficial da União 2020; 7 fev.

15. República del Perú. Decreto Supremo no 0832020-PCM. Prórroga del Estado de Emergencia por coronavirus hasta el 24 de mayo de 2020. https://www.gob.pe/institucion/ pcm/normas-legales/565601-083-2020-pcm (accessed on 03/Jun/2020).

16. Cordero DF. Conoce las normas que ha expedido el Distrito por coronavirus en Bogotá. https://bogota.gov.co/mi-ciudad/gestion-ju ridica/normas-expedidas-por-el-distrito-porel-coronavirus-en-bogota (accessed on 03/ Jun/2020).

17. Goethals L, Barth N, Guyot J, Hupin D, Celarier T, Bongue B. Impact of home quarantine on physical activity among older adults living at home during the COVID-19 pandemic: qualitative interview study. JMIR Aging 2020; 3:e19007.

18. Bezerra ACV, Silva CEM, Soares FRG, Silva JAM. Factors associated with people's behavior in social isolation during the COVID-19 pandemic. Ciênc Saúde Colet 2020; 25 Suppl 1:2411-21.

19. Berg R, Varsori A. COVID-19 is increasing the power of Brazil's criminal groups. https:// blogs.lse.ac.uk/latamcaribbean/2020/05/28/ covid-19-is-increasing-the-power-of-brazilscriminal-groups/ (accessed on 05/Jul/2020).

20. Sarmiento OL, Díaz del Castillo A, Triana C, Acevedo M-J, González S, Pratt M. Reclaiming the streets for people: insights from Ciclovías Recreativas in Latin America. Prev Med 2017; 103S:S34-40.
21. Sarmiento OL, Rios AP, Paez D, Quijano K, Fermino R. The Recreovía of Bogotá, a community-based physical activity program to promote physical activity among women: baseline results of the natural experiment $\mathrm{Al}$ Ritmo de las Comunidades. Int J Environ Res Public Health 2017; 14:633.

22. Cortinez-O’Ryan A, Albagli A, Sadarangani K, Aguilar-Farias N. Reclaiming streets for outdoor play: A process and impact evaluation of "Juega en tu Barrio" (Play in your Neighborhood), an intervention to increase physical activity and opportunities for play. PLoS One 2017; 12:e0180172.

23. Rios AP, Diaz Del Castillo A, Pinzón E, Lozano O, Almanza A, Ruíz N, et al. Al ritmo de las comunidades "Experiencias Inspiradoras En América Latina. Bogotá: Facultad de Medicina, Universidad de los Andes; 2016.

24. Ozamiz-Etxebarria N, Dosil-Santamaria M, Picaza-Gorrochategui M, Idoiaga-Mondragon N. Stress, anxiety, and depression levels in the initial stage of the COVID-19 outbreak in a population sample in the northern Spain. Cad Saúde Pública 2020; 36:e00054020.

25. Ghosal S, Sinha B, Majumder M, Misra A. Estimation of effects of nationwide lockdown for containing coronavirus infection on worsening of glycosylated haemoglobin and increase in diabetes-related complications: a simulation model using multivariate regression analysis. Diabetes Metab Syndr 2020; 14:319-23.
Submitted on 29/Jun/2020

Final version resubmitted on $10 / \mathrm{Jul} / 2020$

Approved on 05/Aug/2020 